\title{
Input Use Efficiency in Sunflower Production; A Case Study of Konya Province (Karatay District)
}

\author{
Cennet Oğuz ${ }^{1, a}$, Aysun Yener Ögür ${ }^{1, b, *}$, Aycan Ayhan ${ }^{1, c}$
}

${ }^{1}$ Department of Agricultural Economics, Faculty of Agriculture, Selçuk University, 42250 Konya, Turkey

"Corresponding author

\begin{tabular}{l|l}
\hline A R T I C L E I N F O & A B S T R A C T \\
\hline Research Article & $\begin{array}{l}\text { The aim of the study is to analyse the efficiency of input use in sunflower production in Karatay } \\
\text { district. Turkey ranks } 10^{\text {th }} \text { in sunflower production in the world and Konya province has } 13.39 \% \\
\text { capacity of sunflower production in Turkey, placing the } 2^{\text {nd }} \text { place in terms of production. } 97 \% \text { of } \\
\text { sunflower produced in Konya province is sunflower for oil. Data used in this study was determined } \\
\text { as } 51 \text { enterprises manufacturing sunflower according to the Stratified Sampling Method. The } \\
\text { economic efficiency results of sunflower production were calculated with Data Envelopment } \\
\text { Analysis (DEAP) method. The total Gross Production Values (GPV) obtained from the enterprises }\end{array}$ \\
$\begin{array}{l}\text { Received : } 24 / 09 / 2019 \\
\text { Accepted : } 24 / 10 / 2019\end{array}$ & $\begin{array}{l}\text { is } 36,221.43 \$, \text { the GPV acquired from the sunflower production is } 23,844.70 \$, \text { the total gross profit } \\
\text { economic efficiency was found to be } 0.604, \text { resource efficiency was } 0.604, \text { technical efficiency was } \\
0.868, \text { and pure efficiency was } 0.922 \text { while scale efficiency was } 0.942 . \text { It should be ensured that }\end{array}$ \\
$\begin{array}{l}\text { Keywords: } \\
\text { DEAP } \\
\text { Economic analysis } \\
\text { Konya } \\
\text { Sunflower production }\end{array}$ & $\begin{array}{l}\text { enterprises use their resources effectively. Information meetings should be held for enterprises on } \\
\text { resource use. }\end{array}$
\end{tabular}

Regression analysis resource use.

Regression analysis


efficiency of the enterprises were calculated in the Karatay district, constituting the majority of the sunflower production. Sunflower production was examined based on enterprises and scale analysis was conducted. Additionally, the amount of inputs used in production, cost and efficiency analyses were carried out according to the sources of efficiencies.

\section{Material and Method}

The main material of the study is composed of the original data collected from the surveys of the enterprises producing sunflower in the year 2015 in Karatay district of Konya Province, which was selected as the research region. In addition, the data that the relevant institutions and organizations previously gathered on the subject was also benefitted.

In the study, stratified sampling method, was utilized in order to increase the accuracy of the data collected from the enterprises and to provide sufficient representation of different sections in the population (Yamane, 1967; Güneş and Arkan, 1988). Layer widths are grouped to 1-50 decares (one tenth of a hectare), 51-150 decares, 151 decares and above. Sample volume was calculated as $51 \%$ according to the Neyman Method with a margin of error of $5 \%$ at a confidence interval of $99 \%$ (Yamane, 1967).

$$
\begin{gathered}
\mathrm{n}=\frac{\sum(\mathrm{Nh} \cdot \mathrm{Sh})^{2}}{\mathrm{~N}^{2} \cdot \mathrm{D}^{2}+\sum \mathrm{Nh} \cdot(\mathrm{Sh})^{2}} \\
\mathrm{D}^{2}=\left(\frac{\mathrm{d}}{\mathrm{t}}\right)^{2}
\end{gathered}
$$

$\mathrm{n} \quad=$ Number of samples,

$\mathrm{N}=$ Number of enterprises in the population,

$\mathrm{N}_{\mathrm{h}}$ = Number of enterprises in h layer,

$\mathrm{S}_{\mathrm{h}} \quad=$ Variance of $\mathrm{h}$ layer,

$\mathrm{d}=$ The margin of error allowed from the population average,

$\mathrm{t}=\mathrm{t}$ table value corresponding to the $99 \%$ confidence limit predicted in the study.

The distribution of the sample volume according to the enterprise groups is given in Table 1.

Table 1 Sample Volume by Enterprise Size Groups in the Research Field (n)

\begin{tabular}{l|c}
\hline Enterprise Size Groups (decare) & Sample Size (n) \\
\hline $0-50\left(1^{\text {st }}\right.$ Group) & 7 \\
$51-150\left(2^{\text {nd }}\right.$ Group $)$ & 9 \\
$151-+\left(3^{\text {rd }}\right.$ Group $)$ & 35 \\
\hline Total & 51 \\
\hline
\end{tabular}

In the research area, if the enterprises gain $30 \%$ or more of their income from sunflower, these enterprises are defined as "the enterprises that produce sunflower" (Oğuz, 1991). Various literatures were used in the calculation of economic activity results of enterprises (Oğuz and Altıntaş, 2002; Semerci, 2014; Oğuz and Bayramoğlu, 2018). In this study, 1 US\$ $=2.56$ Turkish Liras calculated (approximately, in Temmuz 2015).
In the study, the efficiency analysis of sunflower producing enterprises was conducted according to Data Envelopment Analysis (DEA). The Data Envelopment Analysis (DEA) of nonparametric methods measures the relative efficiencies of $n$ number decision-making unit. This method is used to measure the performance of decision units that are similar to each other by determining the weights of inputs and outputs in production relations with multiple inputs and multiple outputs (Coelli, 1996). In addition, it reveals efficiency scores that express the relationship between DEA and input-output and enables the adjustment of inputs and outputs for more efficient use of resources. It distinguishes between efficient and inefficient enterprises and designates the most suitable reference set for inefficient enterprises to become effective (Güngör and Demirgil, 2005; Tosun and Aktan, 2010). Technical activity in DEA is divided into two as pure technical efficiency and scale efficiency. Measurement of the pure technical efficiency is calculated by efficiency limit estimation under the assumption of variable return according to the scale. The ratio of technical efficiency to pure technical efficiency indicates the scale efficiency (Kumar and Gulati, 2008; Coelli et al., 1998). There are Charnes-Cooper-Rhodes (CCR) and Banker-Chaenes-Cooper (BCC) models in DEA. Since the farmers are in a position to control the inputs more than the outputs, Farrell's efficiency measurements for input were used in this study. A multi-input-single output model was created for business groups. Economic efficiency of the input for each individual business was obtained with the solution of the following linear programming model:

The formula description is as below;

Min $\lambda_{\mathrm{xi}} \mathrm{W}_{\mathrm{i}} \times \mathrm{X}_{\mathrm{i}}$

K1sit- $\mathrm{y}_{\mathrm{i}}+\mathrm{y} \lambda \geq 0$

$\theta_{\mathrm{xi}}-\mathrm{X}_{\lambda} \geq 0$

$\lambda \geq 0$

$\mathrm{Wi}=$ Vector of input prices for the enterprise in the I ranking

$\mathrm{Xi}=$ Vector of input-quantity-cost minimization calculated for the enterprise in the I ranking,

$\mathrm{Yi}=$ output level

$\Lambda=$ constant vector

The efficiency value for the enterprises in the ranking of $\mathrm{X}_{\mathrm{i}} \times \mathrm{i}$ is between 0 and 1 . The fact that $\mathrm{Xi}$ value is equal to 1 indicates that enterprises have technical efficiency. For inefficient enterprises, on the other hand, the value of $\mathrm{Xi}$ is less than 1 (Coelli, 1998). Banker et al. (1984) developed Data Envelopment Analysis (DEA) model, which is based on Constant Return to Scale (CRS) assumption, in the way to take Variable Return to Scale (VRS) into consideration and this model is known as BCC. Indeed, if none of the production units operates at the optimal scale, the use of the constant return definition according to the scale results in a measure of technical efficiency mixed with scale efficiencies. Therefore, a limiting factor $\left(\mathrm{N} 1{ }^{\prime} \lambda=1\right)$ providing convex to CRS model, was added and the model was transformed into a VRS model. Because the addition of this limitation to the model hinders the calculation of scale efficiency, the minimum cost in CRS conditions was calculated by proportioning the minimum cost to the VRS conditions when calculating the scale efficiency. DEA was conducted in DEAP 2.1 package program. 


\section{Results and Discussion}

Socio-economic conditions of the enterprises in the research area are given in Table $2.76 .47 \%$ of the producers are primary school graduates, $13.73 \%$ are secondary school and $9.80 \%$ are high school graduates.

The high level of education is quite pivotal for producers to realize production that is more conscious and to be open to innovations. $54.90 \%$ of the producers in the analysed enterprises are in the 15-49 age group constituting the active population. In the research area, sunflower production goes on for more than averagely 11 years.

The usage status of the land for the enterprises analysed is examined in Table 3. According to table 3, average field with per enterprise is 235.20 and is over Turkey's average, 59.90 decares (TSI, 2019). Turkey constitutes $8.14 \%$ of the total agricultural area of the province of Konya. Turkey constitutes $8.14 \%$ of the total agricultural area of the province of Konya. Therefore, agricultural land in the field of research has increased above the average of Turkey.

Of the enterprise lands, sunflower covers $41.17 \%$ of the land, $30.72 \%$ in wheat, $12.86 \%$ barley, $6.05 \%$ corn, $5.88 \%$ beet, $2.99 \%$ other and $0.32 \%$ silage corn production. The largest cultivation area of the enterprises goes to sunflower.

Wheat, barley, grain corn, beet, other products and silage corn are followed by sunflower. $75.48 \%$ of the land used by the enterprises is owned lands, $25.52 \%$ is rental. In a similar study, the average field width of enterprises is 190.8 decares and $81.94 \%$ self-owned field, $10.33 \%$ rental and $7.73 \%$ is common land (Gündoğmuş, 1998).

Gross production values (GPV) of the enterprises are given in Table 4. Average GPV of the enterprises analysed is 50,221.43 \$ according to table 4. In the first group of the enterprise, the value was determined as 6,708.42 \$, $19,487.09 \$$ in the second group and $66,827.14 \$$ in the third group (Table 4 ). Total variable costs in the enterprises analysed in the research area are given in Table 5.

Total variable costs in the enterprises are 13,294.14 \$ and constituted by $28.60 \%$ seed, $20.77 \%$ fuel, $15.92 \%$ water, $14.48 \%$ fertilizer, $11.36 \%$ labour, $5.33 \%$ marketing, $3.18 \%$ pesticide and application of pesticide.

The gross profit of enterprises in the research area is given in Table 6. Gross profit represents an interest for the capital invested by business manager, the labour force of the employees and family members and the sum of a possible profit and the success of the operator and implies the success of the employee. It is of great importance in showing the success of business organization in enterprises. (Semerci A., 2018).

Total gross profit of the enterprises analysed is $36,927,29$ \$. Gross profit can be calculated for the entire business as well as for each production activity in the enterprise. Total costs of sunflower production in the research area are given in Table 6.

Total variable costs of sunflower in the enterprises analysed are 5,559.54 \$. Of that amount, $34.86 \%$ is fertilizer, $22.73 \%$ fuel, $21.39 \%$ seed, $11.37 \%$ labour, $3.60 \%$ water, $3.55 \%$ pesticide and $2.48 \%$ marketing costs. The total fixed costs used in sunflower production are 2,486.18 \$, 47.09\% land rent, 36.11\% amortization, 9.29\% building repair-maintenance and $7.52 \%$ debt interest. Total cost of the enterprises analysed is 20,597.04\$. $69.10 \%$ that is total variance costs while $30.90 \%$ is total constant costs.

Table 2 Socio-Demographic indicators of producers in sunflower growing enterprises

\begin{tabular}{|c|c|c|c|c|c|c|c|c|c|}
\hline \multirow{2}{*}{\multicolumn{2}{|c|}{ Socio-Demographic indicators }} & \multicolumn{2}{|c|}{$1^{\text {st }}$ group (7) } & \multicolumn{2}{|c|}{$2^{\text {nd }}$ group (9) } & \multicolumn{2}{|c|}{$3^{\text {rd }}$ group (35) } & \multicolumn{2}{|c|}{ Total } \\
\hline & & $\begin{array}{l}\text { Piece } \\
\text { (unit) }\end{array}$ & $\begin{array}{c}\text { Ratio } \\
(\%)\end{array}$ & $\begin{array}{l}\text { Piece } \\
\text { (unit) }\end{array}$ & $\begin{array}{c}\text { Ratio } \\
(\%)\end{array}$ & $\begin{array}{l}\text { Piece } \\
\text { (unit) }\end{array}$ & $\begin{array}{c}\text { Ratio } \\
(\%)\end{array}$ & $\begin{array}{l}\text { Piece } \\
\text { (unit) }\end{array}$ & $\begin{array}{c}\text { Ratio } \\
(\%)\end{array}$ \\
\hline \multirow{3}{*}{ Education } & Primary School & 7 & 13.73 & 7 & 13.73 & 25 & 49.01 & 39 & 76.47 \\
\hline & Secondary School & 0 & 0.00 & 2 & 3.93 & 5 & 9.80 & 7 & 13.73 \\
\hline & High School & 0 & 0.00 & 0 & 0.00 & 5 & 9.80 & 5 & 9.80 \\
\hline \multicolumn{2}{|l|}{ Ratio (\%) } & \multicolumn{2}{|c|}{13.73} & \multicolumn{2}{|c|}{17.66} & \multicolumn{2}{|c|}{68.61} & \multicolumn{2}{|c|}{100,00} \\
\hline \multirow{2}{*}{ Age } & $15-49$ & 3 & 5.88 & 5 & 9.80 & 20 & 39,22 & 28 & 54.90 \\
\hline & $50-+$ & 4 & 7.84 & 4 & 7.84 & 15 & 29.42 & 23 & 45.10 \\
\hline \multicolumn{2}{|l|}{ Ratio (\%) } & \multicolumn{2}{|c|}{13,72} & \multicolumn{2}{|c|}{17,64} & \multicolumn{2}{|c|}{68.64} & \multicolumn{2}{|c|}{100,00} \\
\hline \multirow{2}{*}{ Experience } & $0-10$ & 2 & 3.92 & 1 & 1.96 & 0 & 0.00 & 3 & 5.88 \\
\hline & $11-+$ & 5 & 9.80 & 8 & 15.69 & 35 & 68.63 & 48 & 94.12 \\
\hline \multicolumn{2}{|l|}{ Ratio (\%) } & \multicolumn{2}{|c|}{13.72} & \multicolumn{2}{|c|}{17.65} & \multicolumn{2}{|c|}{68.63} & \multicolumn{2}{|c|}{100.00} \\
\hline
\end{tabular}

Table 3 Land use status and product cultivation (Decare)

\begin{tabular}{|c|c|c|c|c|c|c|c|c|}
\hline \multirow{2}{*}{ Products } & \multicolumn{2}{|c|}{$1^{\text {st }}$ group (7) } & \multicolumn{2}{|c|}{$2^{\text {nd }}$ group (9) } & \multicolumn{2}{|c|}{$3^{\text {rd }}$ group (35) } & \multicolumn{2}{|c|}{ Enterprise Average (51) } \\
\hline & dec & Ratio (\%) & dec & Ratio $(\%)$ & dec & Ratio (\%) & dec & Ratio (\%) \\
\hline Sunflower & 29.00 & 100.00 & 60.22 & 71.69 & 119.83 & 38.00 & 96.84 & 41.17 \\
\hline Wheat & 0.00 & 0.00 & 18.22 & 21.69 & 100.60 & 31.91 & 72.25 & 30.72 \\
\hline Barley & 0.00 & 0.00 & 3.67 & 4.37 & 43.14 & 13.68 & 30.25 & 12.86 \\
\hline Grain Corn & 0.00 & 0.00 & 1.89 & 2.25 & 20.23 & 6.42 & 14.22 & 6.05 \\
\hline Beet & 0.00 & 0.00 & 0.00 & 0.00 & 20.14 & 6.39 & 13.82 & 5.88 \\
\hline Other* & 0.00 & 0.00 & 0.00 & 0.00 & 10.26 & 3.25 & 7.04 & 2.99 \\
\hline Silage Corn & 0.00 & 0.00 & 0.00 & 0.00 & 1.11 & 0.35 & 0.76 & 0.32 \\
\hline Total & 29.00 & 100.00 & 84.00 & 100.00 & 315.31 & 100.00 & 235.20 & 100.00 \\
\hline Ownership Owned & 29.00 & 100.00 & 62.56 & 74.47 & 236.80 & 75.10 & 177.53 & 75.48 \\
\hline Status Rent & 0.00 & 0.00 & 21.44 & 25.53 & 78.51 & 24.90 & 57.67 & 24.52 \\
\hline Total & 29.00 & 100.00 & 84.00 & 100.00 & 315.31 & 100.00 & 235.20 & 100.00 \\
\hline
\end{tabular}


Table 4 Gross production values (GPV) of the enterprises within the scope of the study

\begin{tabular}{|c|c|c|c|c|c|c|c|c|}
\hline & \multicolumn{2}{|c|}{$1^{\text {st }}$ group (7) } & \multicolumn{2}{|c|}{$2^{\text {nd }}$ group (9) } & \multicolumn{2}{|c|}{$3^{\text {rd }}$ group (35) } & \multicolumn{2}{|c|}{ Enterprise Average (51) } \\
\hline & $\$$ & Ratio (\%) & $\$$ & Ratio (\%) & $\$$ & Ratio (\%) & $\$$ & Ratio (\%) \\
\hline Sunflower & $6,708.42$ & 100.00 & $15,520.64$ & 79.65 & $29,412.42$ & 44.01 & $23,844.70$ & 47.48 \\
\hline Wheat & - & 0,00 & $2,903.43$ & 14.90 & $14,170.76$ & 21.21 & $10,237.40$ & 20.38 \\
\hline Barley & - & 0,00 & 0.00 & 0.00 & $9,971.01$ & 14.92 & $6,842.85$ & 13.63 \\
\hline Grain Corn & - & 0,00 & 690.63 & 3.54 & $7,760.02$ & 11.61 & $5,447.38$ & 10.85 \\
\hline Beet & - & 0,00 & 372.39 & 1.91 & $3,994.57$ & 5.98 & $2,807.09$ & 5.59 \\
\hline Other* & - & 0,00 & 0.00 & 0.00 & 260.27 & 0.39 & 178.62 & 0.36 \\
\hline Sweet Corn & - & 0,00 & 0.00 & 0.00 & $1,258.09$ & 1.88 & 863.39 & 1.72 \\
\hline TPPV & $6,708.42$ & 0,00 & $19,487.09$ & 100.00 & $66,827.14$ & 100.00 & $50,221.43$ & 100.00 \\
\hline
\end{tabular}

"Other; Vicia Sativa, Clover, TPPV: Total Plant Production Value

Table 5 Total Variable Costs in the Enterprises Analysed (\$)

\begin{tabular}{|c|c|c|c|c|c|c|c|c|}
\hline & \multicolumn{2}{|c|}{$1^{\text {st }}$ group (7) } & \multicolumn{2}{|c|}{$2^{\text {nd }}$ group (9) } & \multicolumn{2}{|c|}{$3^{\text {rd }}$ group (35) } & \multicolumn{2}{|c|}{ Enterprise Average (51) } \\
\hline & $\$$ & Ratio (\%) & $\$$ & Ratio (\%) & $\$$ & Ratio (\%) & $\$$ & Ratio (\%) \\
\hline Seed & 294.82 & 16.71 & $1,022.48$ & 22.95 & $5,218.87$ & 29.20 & $3,802.48$ & 28.60 \\
\hline Fuel & 362.50 & 20.55 & 973.96 & 21.86 & $3,701.14$ & 20.71 & $2,761.63$ & 20.77 \\
\hline Water Price & 172.43 & 9.77 & 516.49 & 11.59 & $2,916.82$ & 16.32 & $2,116.55$ & 15.92 \\
\hline Fertilizer & 531.82 & 30.15 & $1,147.04$ & 25.74 & $2,471.84$ & 13.83 & $1,971.77$ & 14.83 \\
\hline Labour & 181.25 & 10.27 & 425.35 & 9.55 & $2,054.88$ & 11.50 & $1,510.15$ & 11.36 \\
\hline Marketing & 164.62 & 9.33 & 210.50 & 4.72 & 945.87 & 5.29 & 708.87 & 5.33 \\
\hline Pesticide & 56.64 & 3.21 & 159.72 & 3.58 & 563.53 & 3.15 & 422.70 & 3.18 \\
\hline TVC & $1,764.08$ & 100.00 & $4,455.54$ & 100.00 & $17,872.94$ & 100.00 & $13,294.14$ & 100.00 \\
\hline
\end{tabular}

TVC: Total Variable Costs

Table 6 Total Gross Profit by Business Groups (\$)

\begin{tabular}{l|cccc}
\hline & $1^{\text {st }}$ group (7) & $2^{\text {nd }}$ group (9) & $3^{\text {rd }}$ group (35) & Enterprise Average (51) \\
\hline Total GPV & $6,708.42$ & $19,487.09$ & $66,827.15$ & $50,221.43$ \\
TVC & $1,764.08$ & $4,455.54$ & $17,872.94$ & $13,294.14$ \\
TGP & $4,944.34$ & $15,031.55$ & $48,954.21$ & $36,927.29$ \\
\hline
\end{tabular}

TVC: Total Variable Costs, TGP: Total Gross Profit

Table 7 Total Costs of Sunflower Production by Business Groups $(\$)$

\begin{tabular}{|c|c|c|c|c|c|c|c|c|}
\hline \multirow[b]{2}{*}{ Variable and Fixed Costs } & \multicolumn{2}{|c|}{$1^{\text {st }}$ group (7) } & \multicolumn{2}{|c|}{$2^{\text {nd }}$ group (9) } & \multicolumn{2}{|c|}{$3^{\text {rd }}$ group (35) } & \multicolumn{2}{|c|}{ Enterprise Average (51) } \\
\hline & $\$$ & $\begin{array}{c}\text { Ratio } \\
(\%)\end{array}$ & $\$$ & $\begin{array}{c}\text { Ratio } \\
(\%)\end{array}$ & $\$$ & $\begin{array}{c}\text { Ratio } \\
(\%)\end{array}$ & $\$$ & $\begin{array}{c}\text { Ratio } \\
(\%)\end{array}$ \\
\hline Fertilizer Cost & 531.82 & 17.74 & $1,107.20$ & 21.84 & $2,318.35$ & 24.42 & $1,938.38$ & 24.09 \\
\hline Fuel Cost & 362.50 & 12.09 & 752.78 & 14.85 & $1,497.86$ & 15.78 & $1,264.11$ & 15.71 \\
\hline Seed & 294.82 & 9.84 & 743.60 & 14.67 & $1,392.96$ & 14.67 & $1,189.24$ & 14.78 \\
\hline Labour & 181.25 & 6.05 & 376.39 & 7.42 & 748.93 & 7.89 & 632.05 & 7.86 \\
\hline Water Price & 172.43 & 5.75 & 176.21 & 3.48 & 211.61 & 2.23 & 200.50 & 2.49 \\
\hline Pest Cost & 56.64 & 1.89 & 117.62 & 2.32 & 234.04 & 2.47 & 197.52 & 2.45 \\
\hline Marketing Cost & 164.62 & 5.49 & 130.21 & 2.57 & 141.18 & 1.49 & 137.74 & 1.71 \\
\hline Total Variable Cost & $1,764.08$ & 58.85 & $3,404.01$ & 67.14 & $6,544.93$ & 68.95 & $5,559.54$ & 69.10 \\
\hline Land Rent & 0.00 & 0.00 & 459.20 & 9.06 & $1,587.78$ & 16.73 & $1,170.69$ & 14.55 \\
\hline Amortization & $1,060.27$ & 35.37 & 911.46 & 17.98 & 861.61 & 9.08 & 897.67 & 11.16 \\
\hline Building Repair Maintenance & 145.09 & 4.84 & 169.27 & 3.34 & 263.95 & 2.78 & 230.93 & 2.87 \\
\hline Debt Interest & 27.90 & 0.93 & 125.87 & 2.48 & 234.38 & 2.47 & 186.89 & 2.32 \\
\hline Total Fixed Costs & $1,233.26$ & 41.15 & $1,665.80$ & 32.86 & $2,947.71$ & 31.05 & $2,486.18$ & 30.90 \\
\hline Total Costs & $2,997.34$ & 100.00 & $5,069.80$ & 100.00 & $9,492.63$ & 100.00 & $8,045.71$ & 100.00 \\
\hline
\end{tabular}

Gross profit, absolute profit and relative profit of sunflower production was calculated and given in Table 8. According to Table 8 , the average gross profit of enterprises in the production of sunflower is 18,285.16 \$. In a study conducted in the Thrace region in 2014, the gross profit value of sunflower was calculated as 405.95 euro (553.39\$) (Semerci, 2014). Absolute profit is 10,239.43 \$, but the absolute profit does not correspond to the profitability of the sunflower investment. The profitability of production determines the relative profit. Here, the average relative profitability of the enterprises is calculated as 2,96 . In other words, for every $1 \$$ spent on sunflower investment, a profit of \$ 2.96 was earned. Sunflower cultivation is a profitable investment for the region and it is useful to calculate the unit cost.

The unit cost of sunflower production is given in Table 9. In production of sunflower, the unit production value is $0.20 \$$ and the average of the enterprises' variable costs per unit production $0.14 \$$. 
Table 8 Gross Profit (\$), Absolute Profit (\$) and Relative Profit (\$) in Sunflower Production

\begin{tabular}{l|rrrr}
\hline & $1^{\text {st }}$ group (7) & $2^{\text {nd }}$ group (9) & $3^{\text {rd }}$ group (35) & Enterprise Average (51) \\
\hline Sunflower GPV & $6,708.42$ & $15,520.64$ & $29,412.42$ & $23,844.70$ \\
Total Variance Costs & $1,764.08$ & $3,404.01$ & $6,544.93$ & $5,559.54$ \\
Production Costs & $2,997.34$ & $5,069.80$ & $9,492.63$ & $8,045.71$ \\
Gross Profit & $4,944.34$ & $12,116.63$ & $22,867.50$ & $18,285.16$ \\
Absolute Profit & $1,947.00$ & $7,046.82$ & $13,374.86$ & $10,239.43$ \\
Relative Profit & 2.24 & 3.06 & 3.10 & 2.96 \\
\hline
\end{tabular}

Table 9 Sunflower Unit Production Cost $(\$ / \mathrm{kg})$

\begin{tabular}{l|rrrr}
\hline & \multicolumn{1}{c}{$1^{\text {st }}$ group (7) } & $2^{\text {nd }}$ group (9) & $3^{\text {rd }}$ group (35) & Enterprise Average (51) \\
\hline Production Costs & $2,997.34$ & $5,069.81$ & $9,492.64$ & $8,045.72$ \\
Production Amount & $4,065.01$ & $9,332.46$ & $19,612.62$ & $15,658.98$ \\
Variable Costs & $1,764.08$ & $3,404.01$ & $6,544.93$ & $5,559.54$ \\
Sunflower Costs & 0.29 & 0.21 & 0.19 & 0.20 \\
Variable Costs per Unit Production & 0.17 & 0.14 & 0.13 & 0.14 \\
\hline
\end{tabular}

Table 10 Efficiency Scores of Sunflower Producing Enterprises

\begin{tabular}{l|cccccc}
\hline \multicolumn{1}{c|}{$\mathrm{n}=51$} & Lowest & Highest & Average & $\begin{array}{c}\text { Efficient } \\
\text { Enterprise }\end{array}$ & $\begin{array}{c}\text { Increasing } \\
\text { Returns to Scale }\end{array}$ & $\begin{array}{c}\text { Decreasing } \\
\text { Returns to Scale }\end{array}$ \\
\hline Economic Efficiency & 0.106 & 1 & 0.604 & 5 & 3 & 15 \\
Resource Efficiency & 0.106 & 1 & 0.604 & 5 & 31 & 15 \\
Technical Efficiency & 0.417 & 1 & 0.868 & 12 & 37 & 2 \\
Pure Efficiency & 0.681 & 1 & 0.922 & 19 & 32 & 0 \\
Scale Efficiency & 0.417 & 1 & 0.942 & 15 & 36 & 2 \\
\hline
\end{tabular}

The sale price of sunflower is $0.60 \$$. In this study, economic efficiency, resource efficiency, technical efficiency, pure efficiency and scale efficiency were calculated to measure input use efficiency. Economic efficiency is the ratio of the minimum cost to a predicted cost during the production process. The technical efficiency value is a combination of pure efficiency and scale efficiency. Technically efficient enterprises also provided pure technical efficiency (Coelli et al., 1998).

The average technical efficiency of the enterprises analysed was determined as $86.80 \%$. According to this, sunflower producing enterprises use $13.20 \%$ of their resources inefficiently. In other words, it is stated that the sources used in sunflower production are not used effectively in the enterprises analysed and it is not managed by a good entrepreneurship ability. The value of pure efficiency was determined as $92.20 \%$ according to the average of enterprises and it was determined that the enterprise was not administrated well in terms of management. Scale efficiency was found to be $94.20 \%$ on the average of enterprises and the enterprises were not on the appropriate scale in economic sense. The reason for the low scale efficiency shows that the enterprises do not use their resources rationally and that their management ability is low (Oğuz and Yener, 2018). Owing to the inefficient use of fertilizer and water used in enterprises, the resource efficiency was low and the inefficient use of technology led to low technical efficiency. In fact, when the cost elements in sunflower production reviewed, it is observed that a good part of the total cost belongs to technological tools and equipment. Additionally, the fact that enterprises do not operate at the appropriate scale, negatively affects the economic efficiency (Oğuz and Kaya, 2016).

\section{Conclusion and Suggestions}

The average gross profit of enterprises in the production of sunflower is $18,285.16 \$$. Absolute profit is $10,239.43 \$$, but the absolute profit does not correspond to the profitability of the sunflower investment. The profitability of production determines the relative profit. Here, the average relative profitability of the enterprises is calculated as 2,96. In other words, for every $1 \$$ spent on sunflower investment, a profit of $\$ 2.96$ was earned. Sunflower cultivation is a profitable investment for the region. In production of sunflower, the unit production value is $0.20 \$$ and the average of the enterprises' variable costs per unit production $0.14 \$$. The technical efficiency of the enterprises analysed was determined as $86.80 \%$. Pursuant to that, $13.80 \%$ of enterprises use their resources inefficiently. In other words, it can be mentioned that the resources used in sunflower production are not at the sufficient level in terms of management ability. In addition, scale inefficiency of enterprises affects production costs and yield. The average yields of the enterprises with increasing returns to scale were $425.33 \mathrm{~kg} / \mathrm{dec}$ and the efficiency of the scale was found to be $94.20 \%$. That is, businesses are not on the appropriate scale. The fact that enterprises do not operate at the appropriate scale reduces the economic efficiency. This means that enterprises in this group cannot use their resources effectively. Actually, the increase in cost more than the increase in production means that the optimum operating scale cannot be reached. The optimum operating scale is the point where the marginal revenue is equal to or greater than the marginal cost $(\mathrm{MR} \geq \mathrm{MC})$. It should be ensured that enterprises use their resources effectively. Information meetings should be held for enterprises on resource use. 


\section{References}

Banker RD, Charnes A, Cooper WW. 1984. Some Models for Estimating Technical and Scale Inefficiencies in Data Envelopment Analysis Management Science. 30(9):10781092.

Berk A. 2017. The analysis of relationship between sunflower production and its price by using Koyck model in Turkey. Custose @gronegócio on line - v. 13,n. 4, Out/Dez - 2017. ISSN 1808-2882 www.custoseagronegocioonline.com.br.

Boland M, Domine NM, Korber D, O'brien DM. 2001. Theriault, P. Economic Issues with Sunflowers. Agricultural Experiment Station and Cooperative Extension Service, Kansas State University.

Coelli T, Rao DSP, Battese GE. 1998. An introduction to efficiency and productivity analysis. Kluwer Academic, Boston.

Coelli T. 1996. A Guide to DEAP Version 2,1:a Data Envelopment Analysis Competer Program, Centre for Efficiency and Productivity Analysis, Working Paper.96/08.Armidale. 49 p.

Coelli T. 1998. A multi-stage methodology for the solution of orientated DEA models. Operations Research Letters, 23(35), 143-149.

FAO, 2019. http://www.fao.org/faostat/en/\#data (Erişim Tarihi: 23/10/2019).

Gündoğmuş E. 1998. Ankara İli Akyurt İlçesi Tarım İşletmelerinde Ekmeklik Buğday (Triticum aestivum L.) Üretiminin Fonksiyonel Analizi ve Üretim Maliyetinin Hesaplanmas1, Tr. J. of Agriculture and Forestry 22 (1998) 251-260 (C) TÜBİTAK.

Güneş T, Arikan R. 1988. Tarım Ekonomisi İstatistiği, Ankara Üniversitesi Ziraat Fakültesi Yayınları : 1049, Ders Kitabı: 305, Ankara.

Güngör İ, Demirgil H. 2005. Bölgesel Rekabet Yapısının Bulanık VZA İle Araştırılması, Süleyman Demirel Üniversitesi İktisadi ve İdari Bilimler Fakültesi Dergisi, 10(2), ss. 23-38.
Kumar S, Gulati R. 2008. An Examination of Technical, Pure Technical and Scale Efficiencies in Indian Public Sector Bank Using Data Envelopment Analysis, Eurasian Journal of Business and Econimics, 1 (2), 33-69.

Oğuz C, Altintaş Ö. 2002. Kırıkkale İlinde Çerezlik ve Yağlık Ayçiçeği Yetiştiriciliğinin Üretim Maliyeti ve Fonksiyonel Analizi. S. Ü. Ziraat Fakültesi Dergisi 16 (29): (2002) 39-47.

Oğuz C, Bayramoğlu Z. 2018. Tarım Ekonomisi Kitabı. Atlas Kitapevi, 3.Bask1, 1-222.

Oğuz C, Kaya S. 2016. Factors affecting milk production in dairy farming enterprises and effectiveness analysis: A case study in Konya Province of Turkey. Cust Agronegocio, 12, 121136.

Oğuz C, Yener A. 2018. Productivity Analysis of Dairy Cattle Farms in Turkey: Case Study of Konya Province. Custos e @ gronegócio on line - v. 14, n. 1, Jan/Mar. - 2018. ISSN 1808-2882 www.custoseagronegocioonline.com.br.

Oğuz C.1991. Konya İlinde Kuru Koşullarda Tahıl+ Mercimek Yetiştiren Tarım İşletmeleri İle Tahıl Yetiştiren Tarım İşletmelerinin Ekonomik Faaliyet Sonuçlarının Değerlendirilmesi. ÇÜ Fen Bilimleri Enst. Tarım Ekonomisi Anabilim Dalı. Çukurova Üniversitesi.

Semerci A. 2014. The Place and Importance of Cultivating Sunflower (Helianthus annuus L.) in Agriculture Enterprises in Turkey: A case study of Thrace Region. Custos e @gronegócio on line - v. 10, n. 2 - Abr/Jun - 2014. ISSN 1808-2882 www.custoseagronegocioonline.com.br.

Semerci A. 2018. Gross profit analysis in olive oil production: a case study of Hatay Region-Turkey. CUSTOS E AGRONEGOCIO ON LINE, 14(2), 237-259.

Tosun Ö, Aktan HE. 2010. SSK Hastanelerinin Sağlik Bakanlığı'na Devrinin Hastane Verimlilikleri Üzerinde Etkileri. TİSK Akademi, Say1 5, Cilt 10, Sayfa 112-129.

TSI. 2019. http://www.tuik.gov.tr/Start.do (Erişim Tarihi: 20/02/2019).

Yamane T. 1967. Elementary Sampling Theory. Prentice-Hall Inc.Englewood Cliffs, New Jersey. 